\title{
La "nueva" Doctrina Monroe de 1895 y sus implicaciones para el Caribe español: algunas interpretaciones coetáneas españolas *
}

\author{
Sylvia L. Hilton \\ Universidad Complutense, Madrid
}

El análisis de una selección de periódicos españoles de diversas ideologías políticas demuestra que la mayoría de los comentaristas relacionaban la política de Cleveland en la disputa anglo-venezolana en 1895 con la de McKinley en la crisis colonial española de 1895-1898, interpretando ambas intervenciones como una función de la Doctrina Monroe. Sin embargo, al contrario que el presidente Cleveland, McKinley no apeló a esta Doctrina como justificación de su política exterior iberoamericana o de su actitud ante la guerra hispano-cubana, por lo que se interpreta que las referencias a ella en el discurso periodístico peninsular de estos años obedecen a móviles más relacionados con los resortes y objetivos de la propia retórica periodística, dentro del contexto de la política española, tanto doméstica y colonial como internacional. Esto explica las contradicciones y diferencias interpretativas en torno a la Doctrina Monroe que se reflejan en la prensa española.

\section{La Doctrina Monroe}

Provocó un verdadero revuelo internacional la extraordinaria interpretación dada a la Doctrina Monroe en 1895 por el presidente Cleveland y su secretario de Estado Richard Olney, a raíz de su intervención en la disputa anglo-venezolana sobre los límites de la Guayana Británica. En síntesis, la 'nueva' Doctrina Monroe daba el derecho a los Estados Unidos a intervenir en casi cualquier conflicto surgido en América entre una potencia europea y otra americana. "Hoy los Estados Unidos son prácticamente soberanos en este continente, y su fiat es ley respecto de los asuntos a los cuales confinan su interposición". ${ }^{1}$

Así pues, en 1895 la Doctrina Monroe fue protagonista principal de una grave crisis anglo-americana, captando la atención de todo el mundo occidental. De nuevo en 1900-1902, durante los debates en torno a la Enmienda Platt, y sobre todo en 1904, cuando el presidente Roosevelt reivindicó para los Estados Unidos la función de policía internacional en el hemisferio americano, esta Doctrina volvió a protagonizar la política exte-

* Trabajo realizado dentro del proyecto de investigación PB 96-0868 (DGES).

1 Richard Olney a Thomas F. Bayard, 20 de julio de 1895, en Papers Relating to the Foreign Relations of the United States, 1895. Washington, DC., 1896, t. I, págs. 545-562. 
rior estadounidense. En cambio, durante la crisis de 1898 el "gran dogma americano" brilló por su ausencia en los discursos justificativos de la política del presidente McKinley; intrigante ausencia que hemos analizado en otro trabajo. ${ }^{2}$

En noviembre de 1896, superada ya la crisis anglo-americana, los periódicos franceses Le Temps y Le Figaro comentan la actitud británica. Los diarios galos la califican como egoísta, al aceptar la interferencia de Estados Unidos e implícitamente la 'nueva' Doctrina Monroe, y sugieren que España sufrirá las consecuencias de este nuevo ensanche del monroísmo, porque crecerán las pretensiones estadounidenses respecto de Cuba. El periódico madrileño La Epoca rechaza rotundamente esta sugerencia, afirmando que el conflicto hispano-cubano no tiene nada que ver con el caso anglo-venezolano. ${ }^{3}$ La historiografía posterior ha tendido a reforzar este análisis, pues pocas obras se plantean siquiera alguna comparación o relación entre la intervención de Cleveland de 1895 y la de McKinley de $1898 .{ }^{4}$ No obstante, otros comentaristas españoles coetáneos sí que perciben rápidamente la relación entre ambos casos, discutiendo las posibles implicaciones para la crisis colonial española de la reciente extensión de la Doctrina Monroe. Así, en 1898 un considerable número de periodistas españoles interpretarán la intervención estadounidense en la guerra hispano-cubana como una función de la Doctrina Monroe, a pesar de que McKinley no apela a ella en ningún momento. El objeto de este estudio es, pues, analizar algunas de las interpretaciones aparecidas en la prensa española sobre este tema. ${ }^{5}$

2 Dicha ausencia alcanza no sólo las justificaciones oficiales, sino incluso los debates del Congreso, donde las apelaciones a la Doctrina Monroe aparecen mucho más a menudo en boca de los anti-imperialistas. En la historiografía especializada sobre la carrera política de McKinley o las causas de la guerra hispano-norteamericana de 1898, no se halla ningún análisis de esta ausencia. Véase Hilton, Sylvia L., y Steve J.S. Ickringill: “'Its Fiat Is Law'?: McKinley's Strange Silence on the 'Great American Dogma' in 1898". Norms and Authority. Actes du GRENA. (Groupe de Recherche et d'Etudes Nord-Americaines), 29-30 mars 1996. Aix-en-Provence, Université de Provence. En prensa.

3 "Europa y los Estados Unidos", La Epoca, 16 de noviembre de 1896, 3/1.

4 Véase Ickringill, Steve J.S. y Sylvia L. Hilton: "Cleveland and the Anglo-Venezuelan Dispute in 1895: A Prelude to McKinley's Intervention in the Spanish-Cuban War". En: Fusi, Juan Pablo, y Antonio Niño, eds.: Antes del 'Desastre': Orígenes y Antecedentes de la crisis del 98. Madrid, 1996, págs. 337-358.

5 Para un análisis de la historiografía española sobre la prensa peninsular ante la guerra, véase Hilton, Sylvia L.: "The Spanish-American War of 1898: Queries into the Relationship between the Press, Public Opinion and Politics". Revista Española de Estudios Norteamericanos, Alcalá de Henares, 1994, vol. 7, págs. 71-87, aunque aquí interesa destacar que concretamente sobre la imagen de Estados Unidos sólo contamos con el valioso estudio pionero de prensa sevillana realizado por Rosario Sevilla Soler: "La intervención norteamericana en Cuba y la opinión pública andaluza", 
En octubre de 1895, La Epoca puntualiza sobre la Doctrina Monroe: "se ha sintetizado impropiamente en la frase: 'América para los americanos'. La declaración de aquel presidente contenía una excepción categórica a favor de las naciones europeas que actualmente conservasen colonias en el Nuevo Mundo, en cuyo caso estaba España". ${ }^{6}$ Esta es, pues, la salvedad que, al menos en principio, establece una garantía para las posesiones europeas existentes en América, y particularmente para las españolas en el Caribe.?

Ahora bien, desde un enfoque ideológico democrático, la Doctrina Monroe encierra, además, principios de alto valor. El republicano Emilio Castelar lo expresa así: "El principio de no intervención es un principio rudimentario de la democracia moderna. Por él y para él surgió el credo de Monroe impidiendo que interviniera en América la terrible alianza del despotismo europeo". ${ }^{8}$ Incluso La Epoca, aun matizando que "no hemos de entusiasmarnos con una doctrina abiertamente hostil a la influencia europea en América", recuerda el origen anti-intervencionista del monroísmo, y reconoce que "es indudable que hay muchas circunstancias que esfuerzan la aplicación de la máxima: "América para los americanos"”.?

\footnotetext{
Anuario de Estudios Americanos, Sevilla, 1986, t. XLIII, págs. 469-516. Para mantener el presente análisis dentro de unos límites razonables de extensión, se ha examinado una selección de periódicos de circulación nacional y diferente orientación ideológica: El Correo Español, en adelante ECE (tradicionalista carlista), La Epoca, LE (liberal conservador canovista), La Vanguardia, LV (liberal informativo catalán), El Liberal, EL (liberal reformista de afinidades republicanas), El Globo, EG (republicano castelariano), La Justicia, $L J$ (republicano moderado salmeroniano), El (Nuevo) País, E(N)P (republicano progresista de inclinaciones socialistas), El Nuevo Régimen, ENR (republicano federalista), y Las Dominicales del Libre Pensamiento, LDLP (republicano radical anti-clerical), diversas recopilaciones de artículos publicados en El Pueblo (republicano), Diario de Cádiz, DC, y La España Moderna, LEM, y de otros escritos y discursos de personajes políticos.

6 "España en América". $L E, 18$ de octubre de 1895, 1/1.

7 Los comentaristas españoles a menudo se remontan a las circunstancias históricas del mensaje de Monroe para explicar su verdadero significado, casi siempre al objeto de subrayar su valor como 'garantía' estadounidense de las colonias existentes en 1823. Véase "Una falsificación". $L J, 30$ de octubre de 1895, 1/2; "Inglaterra y los Estados Unidos". $L E, 3$ de enero de 1896, 1/1, dice que la Doctrina "puede ser juzgada.. como doctrina anti-revolucionaria o conservadora, por las naciones de segundo orden, como España, que aún conservan ricas provincias en aquella parte del mundo"; "La beligerancia de los insurrectos cubanos", "España y los Estados Unidos" y "La diplomacia de los Estados Unidos",en $E L, 18$ de octubre de 1895 (1/2), y 27 de noviembre (1/5) y 6 de diciembre (2/1-2) de 1896; Varela, Luis V.: "España y Estados Unidos. Monroe y Mac Kinley". LDLP, 26 de mayo de 1898, 3/5-4/1. Algunas de estas reconstrucciones históricas llegan a veces al disparate, como en este caso: "los Estados Unidos, por gratitud al oro derramado y a la sangre vertida por los soldados españoles en pro de su independencia, declararon con Monroe que 'América era para los americanos', y ayudaron a los enemigos de nuestra soberanía tan hidalga y gallardamente como era menester...", en "Enseñanzas de la Historia". $L J, 20$ de julio de 1895, 2/1.

8 "Declaraciones del Sr. Castelar". EL, 23 de diciembre de 1896, 1/4.

9 "Inglaterra y los Estados Unidos". $L E, 3$ de enero de 1896, 1/1.
} 
Es más, para Rafael María de Labra, el mensaje original de Monroe no sólo no se hace acreedor de críticas, sino que se considera como digno del mayor elogio, como un gesto glorioso y eficaz en defensa de la autonomía de los pueblos y de los principios democráticos, contra el despótico intervencionismo monárquico europeo en las jóvenes repúblicas hispanoamericanas..$^{10}$ Labra piensa que muchos políticos y publicistas europeos, poco amigos de los Estados Unidos, deliberadamente interpretan esta Doctrina en sentido alarmista, aprovechándose de algunas "impaciencias" y "extravagancias.. de un puñado de hombres", no imputables a toda la nación estadounidense ni a su gobierno, para fomentar el anti-yanquismo popular. ${ }^{11}$ Del mismo modo, al novelista Benito Pérez Galdós tampoco se le escapa cómo los publicistas intentan manipular el sentimiento anti-yanqui para desviar la atención de otros abusos más cercanos: "Dicen que América para los americanos. ¡Vaya una tontería! América para los usureros de Madrid". ${ }^{2}$

Todo ello suscita cierta ambivalencia española respecto de la Doctrina Monroe y la política hemisférica de los Estados Unidos. Durante la mayor parte del siglo XIX, los dirigentes políticos españoles consideran esta Doctrina como una garantía de las colonias españolas — ciertamente no solicitada, quizás no deseada, siempre incómoda y ambigüa-, pero con todo, una salvaguardia contra las apetencias de otras potencias coloniales europeas (e incluso contra las propias veleidades estadounidenses), y por lo tanto, un recurso diplomático que se debe valorar. ${ }^{13}$

Sin embargo, los sucesivos "ensanches" interpretativos de la Doctrina Monroe comienzan a preocupar a los dirigentes y comentaristas políticos

10 Labra, Rafael María de: De la representación e influencia de los Estados Unidos de América en el Derecho Internacional. Madrid, 1877, repr. en Discursos políticos, académicos y forenses. Segunda serie. Madrid, Imp. de Marcelino Burgase, 1886, especialmente págs. 194-195, y El principio de la intervención, 5 de abril de 1881, repr. en Discursos políticos, académicos y forenses. Primera serie. Madrid, Imp. de Aurelio J. Alaria, 1884, pág. 144.

11 Labra: De la representación....., págs. 194-195. No obstante su disposición favorable al mensaje original, Labra reconoce en Aspecto internacional de la cuestión de Cuba (Madrid, 1900, págs. 76 y 235), que se han producido cambios sensibles en su interpretación por diferentes gobiernos estadounidenses, señaladamente por Polk en 1844-1848, Blaine en 1889, y Cleveland en 1895, aunque insiste que "La interpretación abusiva que se ha dado a la política y las fórmulas del presidente Monroe, sobre todo a partir de 1850, no puede ser bastante para que se niegue el alto sentido y el valor jurídico de la transcendental protesta de 1823, en favor de la independencia y la libertad de los pueblos y contra las pretensiones arbitrarias y reaccionarias de la Santa Alianza europea".

12 Pérez Galdós, Benito: Fortunata y Jacinta, (1887-1888). Edición de F. Caudet. Madrid, 1994, t. I, pág. 541.

13 Para un lúcido análisis coetáneo de este aspecto, que además ha sido muy poco valorado por la historiografía sobre el 98, véase Labra: Aspecto internacional...., especialmente págs. 167-183. 
españoles de finales del siglo XIX, en vista del declarado deseo de los Estados Unidos de comprar Cuba, sus inversiones en la isla y la creciente dependencia comercial del azúcar cubano respecto de ese mercado. ${ }^{14}$

\section{Cleveland, Venezuela y Cuba}

Cuando estalla la crisis anglo-americana de 1895, la mayoría de los periódicos españoles coinciden en la opinión, ampliamente compartida en toda Europa, de que la Doctrina Monroe no forma parte ni del derecho público estadounidense, ni, por supuesto, del derecho internacional, por lo que no tiene ningún valor legal ni diplomático, y además no es aplicable al conflicto entre Inglaterra y Venezuela. ${ }^{15}$

Así, La Epoca niega absolutamente el derecho de Cleveland a intervenir. "La invocación de la doctrina de Monroe, para entrometerse en todo lo que afecte a las relaciones entre una potencia americana y otra europea,

14 Gabriel García Tassara, embajador español en Estados Unidos de 1857 a 1867, puede servir como punto de referencia. En cartas de 1865, mantuvo que había dos interpretaciones de la Doctrina Monroe: una puramente defensiva, 'diplomática', y otra más expansiva, popular y 'política', y que el sistema de gobierno estadounidense no permitía prever cuál de ellas prevalecería en el futuro, por lo que España debía estar prevenida. Oltra, Joaquín: "El poeta García Tassara y la Doctrina de Monroe". Revista de Estudios Políticos. Madrid, septiembre-octubre de 1972, n. ${ }^{\circ}$ 185, págs. 288-310. El reinicio de la lucha cubana en 1895 suscita alusiones a la amenaza monroísta: "No se debe olvidar que hay una potencia, Estados Unidos, que quiere contrarrestar la presencia europea en América y que aprovechará cualquier circunstancia para crearnos problemas". DC, 18 de marzo de 1895, cit. en Baraja Montaña, Manuel: La guerra de independencia cubana a través de Diario de Cádiz, 1895-1898. Cádiz, 1979, pág. 169. En la misma obra (págs. 233-235), se reproduce otro artículo del $D C$ de 8 de septiembre del mismo año, "La insurrección cubana y los periódicos extranjeros", firmado por Emilio Castelar, en el que evidenciando una inquietud similar afirma que "digan cuanto quieran esos yankis, tan enemigos de nuestro dominio en América, y que predican una especie de panamericanismo muy semejante al moscovita paneslavismo, a nadie conviene como a ellos la continuación en Cuba de nuestra España". Con cierta incoherencia, critica a los Estados Unidos por no proteger a las repúblicas hispanoamericanas contra las agresiones europeas, y por "el pensamiento de dilatar sobre todo el Nuevo Mundo, interpretando a lo yanki la doctrina de Monroe, política tutela".

15 Véase por ejemplo "La cuestión de Venezuela", "Cleveland y Salisbury", "La cuestión anglo-americana", "Inglaterra y los Estados Unidos", "La cuestión anglo-venezolana", "Notas de última hora", "Inglaterra y los Estados Unidos", en $L E, 24$ de octubre (1/1), 19 (2/4), 20 (1/5), 22 (1/1) y 24 (3/2 y 3/3) de diciembre de 1895, y 3 de enero de 1896, 1/1; "España en América", "El conflicto angloamericano", "El asunto de Venezuela" y "El conflicto angloamericano", en EP, 25 de octubre (1/2) y 26 (1/3 y 2/3) y $30(2 / 2)$ de diciembre de 1895 . "El conflicto anglo-venezolano y la doctrina de Monroe", "El conflicto angloamericano", "La doctrina de Monroe", "El mensaje presidencial" y "Síntesis política europea", en $L V, 6(1 / 4-2 / 1)$ y 15 (4/3-4 y 6/2) de noviembre y 20 de diciembre (5/3) de 1895 , y 10 de enero (4/1-2) de 1896. "Mensaje importante”, "Conflicto venezolano” y “'Solos!”, en $L J$, de 18 (2/5) y 21 (2/1) de dicembre de 1895 y 1 de febrero de 1896, 1/1. "Extranjero-Venezuela", ENR, 28 de diciembre de 1895, 3/1-2; "Carta de Washington. Venezuela y Monroe”, EL, 2 de enero 1896, 1/3-4. 
implica una absorción de América por los Estados Unidos, y un reto a la influencia europea que merecen serio correctivo". ${ }^{16}$ Pocos días después, abunda en esta línea: "no hay en nuestro concepto, la menor probabilidad de que la Gran Bretaña acepte discusión sobre un tema tan vago, tan peligroso y poco diplomático. La mediación de los Estados Unidos en aquel caso, en vez de ser útil, perjudicaría a Venezuela, pues daría a un conflicto sobre rectificación de fronteras, las proporciones de una lucha de dominación, o de exclusión, nada menos que entre los dos continentes: Europa y América" ${ }^{17}$ Por su parte, La Vanguardia afirma: "El presidente Cleveland, a quien antes de ahora se acusó de haber restringido la doctrina de Monroe, le da ahora un alcance que muchos califican de exagerado, añadiendo que ni el mismo Monroe pudo pensar esto jamás, al formular una teoría que no es, después de todo, un principio del derecho de gentes, sino que en definitiva sólo expresa y traduce un estado permanente y fijo de la opinión americana". En suma, juzga que la Doctrina de 1823 no es aceptable ni siquiera "encerrada en su natural sentido y justos límites", y menos aún se puede tolerar "la modernizada doctrina de Monroe", indicando claramente su percepción de que la "novísima interpretación" de Cleveland y Olney representa un importante cambio respecto del mensaje 'original'. ${ }^{18}$

Absolutamente despreciativo es el novelista y diplomático Juan Valera: "Lo que es verdaderamente odioso y ridículo es que ese expansionismo yanki se apoye en la necia doctrina de Monroe. ¿Qué significa racionalmente que América ha de ser para los americanos?¿Dónde están los americanos a quienes América en todo caso pertenece? Los que han dejado vivos los yankees están acorralados como toros bravos en una dehesa o como jabalíes en un coto. Fuera de esto, América es y seguirá siendo, durante muchos siglos, de los europeos". ${ }^{19}$

Ahora bien, legalismos y teorías aparte, el rechazo español a la validez de la 'nueva' Doctrina Monroe de 1895 se hace más rotundo por el

16 "Los Estados Unidos e Inglaterra". $L E, 18$ de octubre de 1895, 2/2.

17 "La cuestión de Venezuela", Ibídem, 24 de octubre de 1895, 1/1.

18 "Estados Unidos: el mensaje del Presidente Cleveland" y "El americanismo contra Europa", $L V, 21$ de diciembre de 1895, 5/3-4 y 23 de enero de 1896, 1/2-3.

19 Juan Valera, en $D C, 13$ de marzo 1896, cit. por Baraja: La guerra de..., pág. 289. Véase además Vilaplana Montes, Manuel: "Juan Valera y la guerra hispano-cubana", Anuario de Estudios Americanos, Sevilla, 1977, T. XXXIV, págs. 589-605. La descalificación moral de la nación estadounidense mediante la condena de su política indígena será habitual en la prensa española de estos años. Véase por ejemplo "De la prensa extranjera sobre la guerra" y las entregas de la novela "Infamias yankees, o el exterminio de los pieles rojas", en EP, 26 abril 1898 (1/4) el primero, y del 17 de abril (2/1-5) al 4 de septiembre (2/1-4) del mismo año las segundas, y la nota 59. 
temor ante la perspectiva de que se utilice para justificar una intervención estadounidense en el conflicto hispano-cubano. Tras la pretensión de Cleveland de intervenir en todas las disputas territoriales suscitadas entre europeos y americanos, la prensa peninsular claramente percibe como amenaza para las posesiones españolas del Caribe este fortalecimiento del secular afán monroísta de ver el hemisferio americano liberado de todo colonialismo europeo. ${ }^{20}$

En principio, la mayoría de los periódicos políticos españoles defienden la soberanía española en Cuba, con o sin recortes, y creen que la postura de neutralidad que mantiene Cleveland en 1895 es aceptable, llegando algunos incluso a elogiar su liderazgo y su conducta hacia España. ${ }^{21}$ Evidentemente, mientras Cleveland permanece en una actitud favorable para los intereses españoles en Cuba, no resulta muy prudente ni diplomático señalar la conexión entre los conflictos anglo-venezolano e hispanocubano desde la perspectiva de la nueva extensión que se acaba de dar a la Doctrina Monroe. A la mayoría de los observadores peninsulares, defensores del mantenimiento del statu quo de las provincias españolas de Ultramar, no les interesa particularizar tanto, ni llamar la atención sobre su propio problema colonial, tan reciente y angustiosamente renovado, estableciendo una comparación entre los dos casos. ${ }^{22}$

20 En seguida se palpa el temor de la posible aplicación de la Doctrina Monroe para justificar la intervención en Cuba. "La actitud de los Estados Unidos con relación a España y Cuba", $L V, 11$ de octubre de 1895, 4/3-4, critica la explotación por la clase política americana de la ignorancia popular: "la parte menos ilustrada de la opinión pública en los Estados Unidos, entre la cual corre, como aplicable a la insurrección cubana, la sabida Doctrina de Monroe (América para los americanos) y se invoca y trae a cuento en todo conflicto o cuestión que surja entre cualesquiera americanos y europeos cualesquiera, sean quienes fueren unos y otros". May, Ernest R.: Imperial Democracy: The Emergence of America as a Great Power. New York, 1961, págs. 85-86, ofrece una especulación interpretativa original, no comentado por otros autores, acerca de los motivos que pudo encerrar el mensaje presidencial de 17 diciembre 1895. Sugiere "puede incluso que Cleveland emitiera el mensaje en parte como advertencia a las potencias europeas que pudiesen aliarse con España" en Cuba.

21 Por ejemplo, "Con y contra España" y "La actitud de los Estados Unidos con relación a España y Cuba", $L V, 10$ (5/2) y 11 (4/3-4) de octubre de 1895; "El mensaje de Cleveland", "Carta de Nueva York", "Inglaterra y los Estados Unidos" y "Carta de Nueva York", LE, 4 de diciembre de 1895 (1/1 y 1/3, 3/2). El mismo periódico, (20 del mismo mes y año, 1/4), dice: "Es muy general aquí, entre la gente sensata, la opinión de que Mr. Cleveland es superior a su partido; yo voy más lejos y digo que en algunas ocasiones, como en el asunto de las islas Hawai y en el de los insurrectos cubanos, el actual Presidente de la República ha demostrado ser superior a su país".

22 Se trata de una manifestación concreta de una actitud general señalada por Gil Munilla, Octavio: “Cuba, problema español, 1891-1898”, Anuario de Estudios Americanos, Sevilla, 1952, t. IX, págs. 499-500: "La intervención más o menos directa de los Estados Unidos se había convertido en una especie de compartido secreto, el silencio patriótico, al que se prohibía implícitamente toda alusión. Y no por razones de prudencia, sino por las mismas que mueven al avestruz a esconder su cabeza". Como se ve, este autor lo interpreta como muestra de irracionalidad. No obstante, el "silencio" a que alude no será tan cerrado. 
Por esta razón, La Epoca informa sin comentario sobre un artículo del periódico londinense The Standard, portavoz de Lord Salisbury, quejándose de la interferencia de Cleveland en la disputa anglo-venezolana, mientras que mantiene una estricta y correcta neutralidad en la guerra cubana. ${ }^{23}$ Tampoco hacen La Justicia y El Liberal más que informar en la página 3 sobre el debate periodístico británico, que intenta trazar una conexión monroísta entre los dos conflictos. ${ }^{24}$

No es que desconozcan los observadores españoles dicha conexión. Sin duda suscribe La Epoca el dicho 'a buen entendedor, pocas palabras', cuando opta por publicar sin comentario las partes del mensaje de Olney que pueden tener mayor aplicación al caso hispano-cubano: "Una distancia de 3.000 millas a través del Océano hace que sea contraria a la naturaleza y que deba, por tanto, condenarse la unión política permanente de un Estado europeo y de un Estado americano. A la distancia kilométrica que separa a Europa de América, se agrega una distancia moral más grande aun, esto es, la que establece la convicción de que si el principio monárquico puede parecer bueno en Europa, tiene que parecer malo en un Continente nuevo. La intervención de una Monarquía en América es sospechosa y puede dar motivo a represalias. Los Estados Unidos no pueden tolerar que ningún Estado de Europa intervenga por medio de la fuerza en ningún Estado americano". ${ }^{25}$ Asimismo, en velada alusión a las implicaciones de todo esto para España, La Epoca, aun negando la validez legal de la Doctrina Monroe, reconoce que el gobierno de los Estados Unidos "tiende a erigirse en representante del Nuevo Mundo en sus relaciones con los Estados de Europa". Añade que "como frase que revela una tendencia del pueblo norteamericano tiene significación y valor indisputables", mostrando tener conciencia de que la importancia de la Doctrina Monroe en el discurso público doméstico estadounidense transciende lo estrictamente legal, entrando en el terreno resbaladizo de la simbología nacional. ${ }^{26}$

El Liberal también tiene cuidado de subrayar la inexistencia de cualquier conexión legal entre ambos casos, al mismo tiempo que recuerda la interpretación 'restrictiva' conservadora de la Doctrina Monroe. Las rela-

23 "Inglaterra y los Estados Unidos", $L E, 8$ de diciembre de 1895, 2/2.

24 "Cosas yankees", $L J, 24$ de diciembre de 1896, 3/2; "España y los Estados Unidos - La prensa inglesa", $E L, 25$ de diciembre de 1896, 3/2.

25 "Notas de última hora", $L E, 24$ de diciembre de 1895, $3 / 3$.

26 "La cuestión de Venezuela", $L E, 24$ de octubre de 1895, 1/1. Sobre el poder simbólico y emocional de la Doctrina Monroe véase por ejemplo Carnegie, Andrew: "The Venezuelan Question", North American Review, febrero, 1896, CLXII/ CCCCLXXI, pág. 142, y Grenville, John A.S.: Lord Salisbury and Foreign Policy: The Close of the Nineteenth Century. London, 1964, pág. 56. 
ciones hispano-estadounidenses en lo tocante a Cuba tienen importantes precedentes, dice, pero que "no lo es, ni tiene nada que hacer en ellos, la doctrina Monroe. Cualquiera que sea el sentido que se la dé, y hay para todos los gustos, la política de los Estados Unidos en Cuba tiene su historia, sus antecedentes y su criterio especial. Aun sin éstos, la doctrina Monroe carecería de aplicación al caso actual, pues según acaba de definirla Mr. Olney, en su nota a Inglaterra sobre la cuestión de Venezuela, esa doctrina consiste en afirmar 'que ninguna potencia europea podrá aumentar por la fuerza sus territorios en el continente americano". ${ }^{27}$

En cambio La Vanguardia no se resiste a la protesta abierta y, respondiendo a la provocación percibida, insiste que la Doctrina no obliga a España a abandonar Cuba, ${ }^{28}$ por mucho que en los Estados Unidos se hable de la relación entre los dos conflictos. ${ }^{29}$ Tampoco anda a la zaga El Liberal en advertir el peligro para las posesiones españolas, ${ }^{30} \mathrm{y}$, por si alguien no se percatase de la conexión, aclara: "Tal vez pregunte alguien:¿Qué tiene que ver Cuba con la cuestión de Inglaterra? Pues no tiene más relación sino que Cuba pertenece a Europa, y Europa, por medio del gabinete de Londres, ha dado un golpe muy duro al pan-americanismo". Entiende que el rechazo de la Doctrina Monroe por Lord Salisbury no hará sino fomentar el belicismo estadounidense, lo cual perjudicará la causa española en Cuba. ${ }^{31}$

Aun más vitriólica es la condena lanzada por Emilio Castelar, cuando la crisis anglo-americana ha entrado ya en vías de solución, pero estando el conflicto hispano-cubano en pleno auge. Lamenta la "entrada en escena de los Estados Unidos, quienes pretenden arrogarse por interpretaciones absurdas y maquiavélicas del dogma de Monroe un arbitraje nato para dirimir pleitos entre las potencias americanas y potencias europeas, amén de un pontificado enriquecido con excomuniones y anatemas que se permiten con insolencia patente y sin derecho alguno sobre nuestro modo de combatir insurrecciones interiores,...". ${ }^{32}$

27 "Los precedentes" e "Inglaterra y los Estados Unidos", EL, 1 de noviembre (1/1) y 19 de diciembre (1/4-5) de 1895. El 4 de enero siguiente (1/4), el mismo periódico ofreció un retrato de James Monroe, sin más texto explicativo que el pie "Quinto presidente de los Estados Unidos. Autor de la fórmula "América para los americanos"".

28 "Con y contra España", $L V, 10$ de octubre de 1895, 5/2.

29 "La política de los Estados Unidos". Ibídem, 10 de noviembre de 1895, 5/4.

30 "Inglaterra y los Estados Unidos". EL, 19 de diciembre de 1895, 1/4-5: "A España, tanto como al primero, interesa que no triunfe la teoría de Monroe, una de las mentiras internacionales que mayor camino han hecho, por la paciencia y la tolerancia de Europa".

31 "Carta de Washington. Venezuela y Monroe", EL, 2 de enero de 1896, 1/3-4.

32 Castelar, Emilio: "Crónica Internacional”, LEM, febrero de 1896, repr. en Castelar, E: Crónica internacional. Edición preparada por Dámaso de Lario, Madrid, 1982, pág. 338. 
El mes siguiente, Emilio Castelar denuncia la amenaza que flota sobre Cuba, apelando a la tradicional interpretación española en una carta abierta al pueblo estadounidense: "Y no invoquéis la doctrina de Monroe, desconociéndola y falseándola. Esta doctrina se revuelve contra la reconquista de América por Europa; mas reconoce la posesión secular de los territorios europeos en ese continente, y con especialidad del territorio antillano". ${ }^{33}$

Sin embargo, no todo son silencios tácticos o desautorizaciones. Algunas voces republicanas adoptan otras posturas. En octubre de $1895 \mathrm{La}$ Justicia, por ejemplo, después de meditar sobre la fortuna de ciertas frases con alto (aunque cambiante) valor propagandístico, define la Doctrina Monroe en términos favorables. "Es nada menos que el reconocimiento de la independencia y autonomía de todo organismo político o de todo ser para el cumplimiento de su propio derecho; es la negación de toda autoridad y soberanía impuesta desde fuera; es la afirmación de la sustantividad de todo cuerpo social para vivir y determinarse lo que se encierra en esas cuatro palabras,.. 'América para los americanos"'. El periódico reconoce la justicia y la inevitabilidad de la propuesta, aun sosteniendo que el momento no ha llegado todavía para Cuba, al tiempo que rechaza de plano la opción anexionista. "España como América se encuentran para la aplicación de la llamada doctrina de Monroe, no allí donde los confeccionadores de cartas geográficas tiñen los continentes de verde o de encarnado, sino en donde palpita el espíritu de nuestra raza. América podrá ser algún día para los americanos; pero España tiene forzosamente que ser para los españoles, y Cuba es un pedazo de España....". ${ }^{34}$

Asombra ver cómo este mismo periódico, en su afán por criticar la política exterior de la Restauración, a los pocos meses se contradice del siguiente modo: "Puede que alguno de los cancilleres de menor cuantía que tiene la restauración para casos de apuro, haya tomado en serio la mal llamada doctrina de Monroe, que no es tal doctrina, ni en rigor es de la inventiva intelectual de Monroe, ni es más que una colección deshilvanada de afirmaciones incoherentes que no suponen que América sea sólo para los americanos. Aun admitiendo que tal pensara Monroe,....". ${ }^{35}$

La comprensión de semejante cambio reside quizás en la tensión creada en el seno de la minoría republicana entre su inclinación ideológica, en principio favorable a la interpretación idealista tradicional de la

33 Castelar: “Crónica Internacional”, LEM, marzo de 1896, Ibídem, pág. 352.

34 "Para los españoles", $L J, 24$ de octubre de 1895, 1/4-5.

35 “'Solos!”, Ibídem, 1 de febrero de 1896, 1/1. 
Doctrina Monroe, y su decisión estratégica de aprovechar todos los recursos retóricos proporcionados por la crisis colonial para desestabilizar el régimen español. ${ }^{36}$ Dicha estrategia se basa en la adopción de una actitud patriótica, irredentista, que critica al gobierno por su ineptitud para resolver el conflicto cubano, y por su debilidad frente a las presiones estadounidenses. Esta postura oportunista naturalmente requiere, a su vez, actitudes condenatorias de los Estados Unidos que no siempre se concilian fácilmente con la propia ideología republicana. ${ }^{37}$

Ahora bien, dentro del panorama periodístico español, los comentarios más incisivos y originales sobre este tema aparecen en el semanario republicano federalista El Nuevo Régimen, redactado en su mayor parte por el jefe e ideólogo de este partido, Francisco Pí y Margall. A mediados de octubre de 1895, justo cuando surge la noticia del enfrentamiento anglo-americano, aparece en este periódico la insinuación (no manifiestamente condenatoria) de que si la Doctrina Monroe da a los Estados Unidos el derecho de intervenir en la disputa anglo-venezolana y en todas las cuestiones europeas en América, quizás se intentará invocarla para justificar su intervención también en el conflicto hispano-cubano ${ }^{38}$ En principio, el órgano federalista coincide con la opinión mayoritaria europea y española de que la Doctrina Monroe no es aplicable al litigio anglo-venezolano, y que Cleveland y Olney han alterado el sentido verdadero del mensaje de $1823 .{ }^{39}$

Pero, desde la perspectiva ideológica federalista, la interpretación de la postura de Cleveland provoca inquietudes más complejas que el simple rechazo. ¿Por qué — se preguntan - intervenir en Venezuela, donde los Estados Unidos no tiene un interés legítimo, y arriesgándose a una guerra contra la poderosa y civilizada Gran Bretaña, al tiempo que se sigue una

36 Sobre la esperanza republicana (y carlista) de que la crisis colonial fuese "el túmulo de la monarquía”, véase por ejemplo, Serrano, Carlos: Final del Imperio: España, 1895-1898. Madrid, 1984, págs. 75-89, y Núñez Florencio, Rafael: "Los republicanos españoles ante el problema colonial: la cuestión cubana (1895-98)", Revista de Indias, Madrid, 1993, T. LIII, n. ${ }^{\circ} 198$, págs. 545-561, que ofrece un buen resumen de algunas actitudes y es útil como punto de partida para este tema.

37 Véase por ejemplo las contradicciones de Emilio Castelar, una de las voces más agresivamente críticas de la política de McKinley (notas 32, 57), pero quien, en "La acción diplomática", $E L$, 17 de enero de 1897, 2/1, tras afirmar que los Estados Unidos no quieren Cuba, que la quieren española, y que una guerra con ellos sería el colmo de la insensatez, dice "Yo republicano, liberal, demócrata, pertenezco a todos aquellos que los creen, por Franklin, por Washington, por Lincoln, por Edison, hijos predilectos de la Humanidad y ornato incomparable del planeta".

38 "Rumores", ENR, 26 de octubre de 1895, 2/1-2.

39 "Extranjero. Venezuela", "América y Europa", "Peligros", y “América y Europa”, en ENR, 28 de diciembre de 1895, 3/1-2, y 4 de enero (1/3), y 9 de mayo (1/3) de 1896. En esa penúltima fecha se escribía: "Fuerza Cleveland la significación y el sentido de la doctrina de Monroe, reducida a vedar a Europa que tome por campo de colonización la América..". 
política de inhibición en Cuba, donde sí tiene un interés patente? Si Cleveland es sincero en la defensa del sentido recto del principio de 'América para los americanos' — su justificación para la intervención en la disputa anglo-venezolana-, debería apoyar todos los movimientos independentistas americanos. Los federalistas españoles comprenden que el pueblo americano simpatice con la causa cubana, que sienta preocupación humanitaria ante las crueldades de la guerra, y que desee proteger sus diversos intereses económicos en la isla, todo lo cual justifica plenamente al gobierno estadounidense en intervenir para promover una paz estable en la isla. Sin embargo, el gobierno de Cleveland, al tiempo que repentinamente hace gala de decisión y energía en el caso anglo-venezolano, muestra debilidad y temor en el caso hispano-cubano. Esto, en el análisis federalista, resulta incomprensible e incluso sospechoso. Habida cuenta de que los federalistas españoles son partidarios de una amplia autonomía (y en última instancia, de la independencia) para Cuba, les desconcierta y les repele lo que perciben como la inconsistencia política de Cleveland en 1895-96: "Esta política de doble faz que en Cleveland observamos no nos es, a decir verdad, simpática". ${ }^{40}$

Más tarde, El Nuevo Régimen volverá sobre la relación entre ambos casos, señalando en octubre de 1897 que los insurgentes cubanos a menudo se quejan de que Estados Unidos no haya intervenido en la guerra hispano-cubana con la misma energía que mostró en la disputa anglo-venezolana; ${ }^{41} \mathrm{y}$ en diciembre del mismo año, contrariando la opinión prevalente en la prensa española sobre el mensaje de McKinley al Congreso, para sostener que una intervención estadounidense en Cuba estaría mucho más justificada que la efectuada en Venezuela. ${ }^{42}$ De hecho, el semanario federalista repite con cierta insistencia la idea de que los Estados Unidos tiene un interés legítimo en que se encuentre una solución civilizada al conflicto cubano, y, confiado en las aparentes buenas intenciones del discurso oficial, contempla con esperanza, e incluso con impaciencia, la intervención diplomática del gobierno estadounidense. ${ }^{43}$ En esta línea, el pacifis-

40 "Cleveland", Ibídem, 21 de diciembre de 1895, 1/4 a 2/1.

41 "La alianza", Ibídem, 23 de octubre de 1897, 1/3-4.

42 "El mensaje de Mackinley. La intervención", Ibídem, 11 de diciembre de 1897, 1/2.

43 "Cuba", "Lo raro es que esos Estados no hayan ya intervenido en la lucha a favor de los cubanos", "Nuestro patriotismo", "La declaración de beligerancia", "La alianza", "El mensaje de McKinley. La intervención", "La guerra de Cuba" y "El 'Maine”, en ENR, 29 de febrero (1/3-4), 28 de marzo (1/2-3) y 11 de abril (2/1) de 1896; 23 de octubre (1/3-4), y 11 de diciembre (1/2 y 1/3) de 1897, y 26 de marzo de 1898, 1/2. En la misma publicación (28 de noviembre de 1896, 1/2-3), en el 
mo federalista no puede menos que manifestar estar en pleno acorde con el principio del arbitraje internacional, como medio de resolver los conflictos internacionales. La poderosa Gran Bretaña se vio obligada por Cleveland a aceptar una solución arbitrada en su disputa con Venezuela, y por lo tanto, ni los Estados Unidos podría obstaculizar una solución similar para el conflicto hispano-cubano, ni España tendría por qué sentirse humillada por avenirse a ello, con tal de evitar una guerra ruinosa contra Estados Unidos. ${ }^{44}$

\section{McKinley}

Quizás la declaración más rotunda que hace William McKinley en apoyo de la Doctrina Monroe sea precisamente su aprobación, en diciembre de 1895, del mensaje de Cleveland al Congreso que, a su juicio, "impone con fuerza y vigor la posición de los Estados Unidos en sus relaciones con las potencias europeas durante más de setenta años. Es norteamericano en letra y espíritu, y su estilo tranquilo y desapasionado sostiene el honor de la nación y garantiza su seguridad" ${ }^{45}$ Su monroísmo parece confirmado en sentido general por la rotunda defensa de la Doctrina incluida en la plataforma republicana para las elecciones presidenciales de 1896, que a su vez refrenda una larga tradición monroísta de este partido. ${ }^{46}$

artículo "La intervención de los Estados Unidos”, F. Pí y Margall reitera la idea de que Estados Unidos tiene un interés mayor en la guerra hispano-cubana que en el litigio anglo-venezolano, y, aun deplorando una posible intervención armada, llega a sugerir que "meramente diplomática, podría ser un bien para ellos, para Cuba, para nosotros y para las demás naciones".

44 "Una entrevista con 'El Liberal"”, ENR, 24 de septiembre de 1898, 2/2-3. Sobre este tema, "La cuestión de Venezuela", $L E, 24$ de octubre de 1895, 1/1, también opinaba que la mediación de los Estados Unidos en el conflicto anglo-venezolano podía considerarse como usual y amistosa, y el arbitraje como un "verdadero adelanto en el derecho público internacional", pero no opinará del mismo modo tratándose del conflicto hispano-cubano.

45 Citado en Gould, Lewis: The Spanish-American War and President McKinley, Lawrence, 1982, pág. 9. Obsérvese que, aunque la alusión a la Doctrina Monroe es inequívoca, McKinley no lo nombra.

46 La plataforma republicana de 1896, además, vincula la Doctrina Monroe al tema cubano, expresando en el mismo párrafo sus simpatías hacia los rebeldes: "Nuestra política extranjera debería ser en todo momento firme, vigorosa, y digna.. Ratificamos la Doctrina Monroe en toda su extensión, y reafirmamos el derecho de los Estados Unidos a darle efectividad respondiendo a la petición de cualquier Estado americano de una intervención amistosa en caso de intrusismo europeo.. Observamos con profundo y constante interés las batallas heroicas de los patriotas cubanos contra la crueldad y la opresión.. Con esperanza anticipamos la futura retirada de las potencias europeas de este hemisferio..”, en National Party Platforms, 1840-1960. Compiled by K.H. Porter and B. Johnson, Urbana, Ill., 1961, págs. 107-109. 
Sin embargo, durante su campaña electoral McKinley apenas menciona la Doctrina Monroe, y tampoco va a incluirla en su discurso público habitual durante sus mandatos, ni en relación con la política general de los Estados Unidos en Iberoamérica, ni en relación con la guerra hispano-cubana. ${ }^{47}$

No obstante, el nuevo presidente es retratado inmediatamente en España como un firme defensor de la Doctrina Monroe. ${ }^{48}$ Hacia finales del año 1897 y a lo largo de los primeros meses de 1898 , se va tejiendo un discurso receloso respecto de la amenaza que supone el auge del 'nuevo' monroísmo para las colonias españolas del Caribe. Pese a que McKinley no hace alusión alguna a esta Doctrina para justificar o explicar sus decisiones cara al conflicto hispano-cubano, varios comentaristas españoles dan por sentado que la intervención será una función del monroísmo republicano.

La Epoca, por ejemplo, ve veleidades monroístas en el mensaje presidencial al Congreso de 1897, comentando que contiene "no pocas declaraciones propicias a España expuestas con claridad y firmeza; pero hay también otras que envuelven la afirmación de la doctrina de Monroe, que limitan los derechos de nuestra patria y que dejan en pie para lo futuro los motivos de conflicto que el Mensaje tiende a alejar en el presente.. Adviértase claramente que mister Mac-Kinley admite y continúa la doctrina de Monroe, puesto que afirma sin vacilar el derecho de los Estados Unidos de intervenir en los destinos de Cuba". ${ }^{49}$ Asimismo, El Correo Español afirma: "Ellos, los yankees, se anexionan las islas Hawai, y quieren anexionarse Cuba y Puerto Rico y toda la América que fue española, disfrazando su ambición con la máxima de Monroe, 'América para los americanos". ${ }^{50} \mathrm{Al}$ mismo tiempo, El Nuevo Régimen advierte que, si no acaba la guerra cubana pronto, McKinley intervendrá en virtud de la Doctrina Monroe..$^{51}$ Por su parte, El País plantea el peligro en términos de

47 Atkins, George P.: "McKinley and Latin America", en Paolo E. Coletta (ed.): Threshold to American Internationalism. Essays in the Foreign Policies of William McKinley. Jericho, NY, 1970, págs. 315-334; Ickringill y Hilton: "Cleveland and...", págs. 351-354, y, sobre todo, de los mismos autores, "“Fiat Is Law'?...", en prensa.

48 "Extranjero-Estados Unidos" y "Mackinley", ENR, 20 de junio (3/3) y 7 de noviembre (1/3-4) de 1896. "Estados Unidos", EP, 10 de noviembre de 1896, 3/3-4, dice que McKinley "es la encarnación de la doctrina de Monroe expuesta por él mismo una vez más en su discurso-programa pronunciado en San Luis". "Contingencias posibles", en EL, 5 de noviembre de 1896, 1/1-2, dice sobre McKinley: "Desde que unió su nombre al famoso bill, cuyos efectos se han hecho sentir en la vida comercial de los dos continentes, tiénenle sus partidarios por heredero legítimo de Monroe. ..En cuanto a la política exterior, desea ampliar la famosa doctrina del quinto presidente de la gran República".

49 "El mensaje de Mac-Kinley. Lo dulce y lo amargo", LE, 7 de diciembre de 1897, 1/1.

50 "Contrastes", ECE, 10 de diciembre de 1897, 1/1.

51 "El mensaje de McKinley. La intervención”, ENR, 11 de diciembre de 1897, 1/2. 
crítica al gobierno español, diciendo que "nos pone en el duro trance de humillarnos ante las imposiciones de los que profesan y practican las doctrinas de Monroe". ${ }^{2}$

El ministro de Ultramar, Segismundo Moret, tampoco tiene dudas y, en discurso ante el Senado, asegura que se ha llegado a la guerra contra los Estados Unidos "porque la política norteamericana, con la doctrina de Monroe, hace ya años que acecha el momento en el cual la isla de Cuba pueda ser suya". ${ }^{33}$

Todavía hay intentos de salvar la interpretación 'restrictiva' tradicional de la Doctrina Monroe. Castelar, criticando "la petulancia de los yankees, empeñados en hacer para todo el Nuevo Mundo la lluvia y el buen tiempo", insiste que "La doctrina de Monroe no corta el cable que une los viejos continentes con el nuevo y no desconoce la maternidad histórica por un derecho natural casi, correspondiente a nuestra madre España para con sus dos Antillas. Todo lo contrario: la doctrina de Monroe proclama la unión eterna e indisoluble de Cuba con su gloriosa Metrópoli" ${ }^{54}$ Por su parte, El Globo comenta con aprobación la opinión de uno de los más prestigiosos teóricos estadounidenses del Derecho. Internacional, el profesor John Basset Moore, para quien Monroe no pensó en establecer ningún tipo de dominio estadounidense sobre toda América, sino en proponer una "doctrina de defensa y no de agresión". ${ }^{55}$

Sin embargo, en vísperas de la ruptura, prevalece en la prensa española el rechazo absoluto a la legitimidad de la Doctrina Monroe, blandiéndose varios argumentos: la simple negación de su validez como norma del

52 "Política incolora", EP, 7 de febrero de 1898, 1/1. De modo similar, "España y los Estados Unidos. El paso de las potencias", ECE, 9 de abril de 1898, 1/1, dice: "lo malo es que con los "yankees', orgullosos con su máxima 'América para los americanos', no se entenderán [nuestros gobernantes] tampoco, y vendrá el conflicto".

53 "El discurso del señor Moret", EG, 7 de mayo de 1898, 1/3.

54 Castelar, Emilio: "Crónica internacional", LEM, enero de 1898, reproducido en Crónica..., pág. 398, y "Justificación de Weyler”, $L D L P, 13$ de enero de 1898, 2/3-5, reiterando que la Doctrina Monroe no sólo no es aplicable para justificar la intervención en Cuba, sino que, al contrario, la prohíbe.

55 "La América del Norte. Recuerdos oportunos", EG, 25 de marzo de 1898, 1/2-3. El conservadurismo de Moore, quien desempeñará importantes cargos en el gobierno de McKinley, se puede ver en The Monroe Doctrine: Its Origin and Meaning, New York, 1895, y "The Monroe Doctrine", Political Science Quarterly, 1986, T. XI, págs. 1-29. Igual defensa de la interpretación 'restrictiva' del mensaje de Monroe se encuentra en Varela, Luis V.: "El fondo de la cuestión”, LDLP, 19 de mayo de 1898, 1/4 a 2/3, y "España y los Estados Unidos. Monroe y Mac Kinley", Ibídem, 26 de mayo de 1898, 3/3 a 4/1: "lejos de prestarse a ninguna teoría internacional que sirva para el ataque, en él sólo se encuentran principios que establecen la defensa". 
Derecho Internacional: $;{ }^{56}$ el desprecio basado en su historial de aplicaciones arbitrarias e hipócritas en casos concretos; ${ }^{57}$ la indignación dolida contra una pretensión que desatiende los lazos históricos entre España y América ${ }^{58}$ la desautorización en tono de sarcasmo de una Doctrina percibida como mero disfraz de una política egoísta, interesada y bárbara al servicio del expansionismo económico. ${ }^{59}$

Incluso los federalistas, debatiéndose penosamente entre su inmensa admiración por los Estados Unidos y las pruebas irrefutables de que está comenzando una nueva etapa en la acción exterior de la 'Gran República', se rinden ante la evidencia de la política de McKinley. ${ }^{60}$ Consumada la derrota, El Nuevo Régimen ya no duda que la intervención estadounidense para poner fin al dominio español en Cuba y Puerto Rico es una manifestación del 'nuevo' monroísmo: "Ha venido ahora en auxilio de los insu-

56 "Regalos austríacos", EP, 11 de abril de 1898, 1/1; La Baronesa de Wilson: América en fin de siglo, Madrid, 1897, pág. 51; Incluso Labra (Aspecto internacional.... págs. 229-230) reconoce que "se había señalado por las cancillerías europeas, y por los más respetados jurisconsultos contemporáneos, la ambiciosa pretensión del Gobierno norteamericano de invocar y practicar una especie de Derecho Internacional de su exclusiva producción y su especial marca", suscitando fuertes protestas a partir de 1895. Así, dice, "las últimas fórmulas de la bastardeada política de Monroe y la aspiración del Gobierno de la Casa Blanca de aparecer, o ser realmente, el protector de todo el Nuevo Mundo, no han pasado desapercibidas y sin contradicción por parte de casi todos los estadistas y tratadistas de nuestro tiempo".

57 Castelar, Emilio: "La acción diplomática”, EL, 17 de enero 1897, 1/2: "Muchos creen que llevan a punta de lanza los americanos el programa de Monroe. ¡Buena será! Les importa una higa. No llaman al traído y llevado programa, ley, derecho, jurisprudencia ni cosa que lo valga, por el respeto religioso de todos los anglosajones al sentido literal de sus códigos. Le llaman doctrina, la doctrina de Monroe.¿Porqué le llaman doctrina? ¿Por interpretarla según la ocasión, la circunstancia, el interés? ¿Les conviene que los franceses no abran el paso por Panamá? Pues invocan la doctrina de Monroe.¿Quieren hacer ellos el paso por Nicaragua? Pues, no teniendo dinero bastante, le ceden la mitad entera del canal a los ingleses contra la doctrina de Monroe. Buen caso le hacen a Monroe. Tal nombre no pasa de una plataforma, como dicen ellos; de un comodín, como decimos nosotros".

58 “Unica solución”, $L D L P, 16$ de abril de 1898, 1/3: “¿Dónde se atreve siquiera la Unión republicana del Norte a invocar la doctrina de Monroe contra una España que tenía en su corazón la mayor parte del corazón americano?".

59 "De la prensa extranjera sobre la guerra", EP, 26 de abril de 1898, 1/4, publica extractos de un artículo de La Patrie que denuncia la política de los Estados Unidos hacia su población indígena y los motivos económicos subyacentes al anexionismo de Cuba: "Esta es sencillamente, toda nuestra doctrina de Monroe y toda nuestra humanidad". "Una opinión sobre la guerra", EG, 5 de mayo de 1898, 2/1, traduce un artículo de Juliette Adam, de La Nouvelle Revue, condenando la hipocresía del pueblo estadounidense que "ha tomado como principio de explotación industrial en el exterior la doctrina de Monroe".

60 "Una consulta", ENR, 23 de julio de 1898, 2/1-2: "Esto es más alarmante. Podría muy bien revelar el pensamiento de arrojarnos totalmente de América y arrojar más tarde de América a las demás naciones de Europa. No se olvide que a la doctrina de Monroe se ha sustituido recientemente la de América para los americanos". 
rrectos de Cuba el ensanche que se ha dado a la doctrina de Monroe. Monroe se limitó a decir que no se debía ni podía tolerar nuevas invasiones de Europa en América; hoy se sostiene que América es para los americanos, y se debe, por lo tanto, expulsar de ella a la intrusa Europa. Por arrojarnos a nosostros se ha iniciado esta política". ${ }^{61}$

\section{La Doctrina Monroe en Europa e Iberoamérica}

Ante la crisis anglo-americana de 1895, la mayoría de las potencias europeas se hacen eco de la demoledora respuesta inicial dada por Lord Salisbury a la nota de Olney. Estos comentarios condenatorios no están inspirados precisamente por un sentimiento de solidaridad o simpatía hacia Inglaterra, sino por la convicción de que esta 'nueva' Doctrina Monroe, aun más que el mensaje original de 1823, amenaza los intereses coloniales y económicos europeos en América. ${ }^{62}$

En España la prensa se hace eco de esta indignación europea generalizada. La previsible aplicación de la 'nueva' Doctrina Monroe de 1895 a todas las dependencias europeas en América, advierte insistentemente la prensa española, tenderá a promover la expulsión de toda Europa del hemisferio americano, por lo que las potencias europeas deben necesariamente hacer causa común con España para disuadir al gobierno estadounidense de una intervención similar en Cuba. ${ }^{63}$

61 “Don Federico Rubio", ENR, 12 de noviembre de 1898, 1/2-3. Para un estudio más detallado de la percepción federalista española de los Estados Unidos en 1898, véase Hilton, Sylvia L.: "República e Imperio: los federalistas españoles y el mito americano (1895-98)", Ibero-Americana Pragensia, Praga, en prensa.

62 Véase por ejemplo, Perkins, Dexter: A History of the Monroe Doctrine, Boston, 1955, págs. 186-189; Seed, Geoffrey: "British Reactions to American Imperialism. Reflected in Journals of Opinion, 1889-1900”, Political Science Quarterly, 1958, n. ${ }^{7}$ 73, págs. 254-272; May, Imperial Democracy...., págs. 186-187.

63 Véase por ejemplo, “Los Estados Unidos e Inglaterra",'La cuestión de Venezuela", "Europa y la doctrina de Monroe", "La beligerancia y la anexión a los Estados Unidos", "Carta de Nueva York", e "Inglaterra y los Estados Unidos", en $L E, 18$ (2/2), 24 (1/1) y 25 (2/2) de octubre, y 5 (2/2), 14 (2/1) y 22 (1/1) de diciembre de 1895; "La alianza europea" o "España en América", EP, 20 (1/1) y 25 (1/2) de octubre y 5 de diciembre (1/5) de 1895; "La doctrina de Monroe", LJ, 20 de diciembre de 1895, 3/3; "Estado de la cuestión", EL, 26 de diciembre de 1896, 1/1; "Peligros" y "Las islas Hawaii", en ENR, 9 de mayo 1896 (1/3), y 19 dejunio de 1897, 2/2. Entre los periódicos que hemos revisado, Tulio, "Aún es tiempo", ECE, 19 de marzo de 1898, 1/1-3, es el que más desconfía de la posible ayuda europea a España. La supuesta creencia mayoritaria en el apoyo europeo apenas repara en que las vehementes críticas periodísticas al 'nuevo' monroísmo de 1895 no se tradujeron en un apoyo (ni europeo ni español) eficaz a Gran Bretaña en esa crisis. 
De hecho, en el verano de 1896 el propio gobierno español pretende advertir oficialmente a las potencias europeas del peligro que representa para sus intereses coloniales y marítimos la cada día más absorbente y expansiva Doctrina Monroe, en un intento claro de promover la solidaridad europea con España frente al creciente intervencionismo y hegemonismo estadounidense en las Américas. ${ }^{64}$

Al convertirse en realidad la amenaza percibida, la supuesta solidaridad europea con la causa española es un tópico ubicuo en la prensa del año 1898. Durante los primeros meses se trata de argumentar que esta circunstancia, si no impide que Estados Unidos declare la guerra a España, asegurará el triunfo europeo y español, mientras que después de la derrota se trata de hacer un melancólico intento de última hora de movilizar la opinión europea contra las excesivas pretensiones estadounidenses, cara a las negociaciones de las condiciones de paz. ${ }^{65}$

La publicación de numerosos resúmenes y glosas de artículos aparecidos en la prensa europea, criticando la más reciente extensión de la Doctrina Monroe, tiene la misma finalidad. ${ }^{66} \mathrm{~A}$ tenor de las referencias aparecidas en los periódicos españoles, gran parte de la prensa francesa se muestra extremadamente vehemente en su anti-yanquismo. En marzo, por ejemplo, El Globo reproduce del diario francés Le Matin un artículo de Henry Girard, simpatizante de la postura española, afirmando que "la

64 El duque de Tetuán, ministro de Estado, Carta circular a los embajadores españoles en Europa, 28 de julio de 1896. Archivo del Ministerio de Asuntos Exteriores, Histórico-Política, leg. 2416. Sobre el contexto diplomático véase Torre, Rosario de la: Inglaterra y España en 1898, Madrid, 1988, págs. 67-72, y Offner, John L.: An Unwanted War: The Diplomacy of the United States and Spain over Cuba, 1895-1898, Chapel Hill, N.C., 1992, págs. 17-36.

65 EP confía en "el apoyo de algunas potencias, grandemente interesadas en que no predomine en América, contra toda ley histórica y de justicia, la doctrina de Monroe"; dice que los Estados Unidos, "armados así en corso contra toda la especie humana, no es extraño que ahora piensen en la anexión de la isla de Cuba como primer paso para arrojar del golfo de Méjico a los europeos"; arguye que la amenaza monroísta motivará a Francia, Inglaterra y Dinamarca para solidarizarse con España frente a los Estados Unidos, recordando una vez más la crisis de 1895: "los Estados Unidos hicieron cuanto les fue posible por atizar la discordia, presentándose en los últimos momentos invocando la doctrina de Monroe para justificar su intervención en el asunto.."; que "es nuestra nación paladín de los derechos europeos en América y valladar opuesto a las desapoderadas ambiciones de los yankis", y asegura que "La doctrina de Monroe es de una increible imprudencia para con los países europeos que tienen intereses en América". "La cuestión de Cuba", "En corso", "Los yankees contra Francia", "Conflictos europeos" y "La prensa yanki y la alemana", en EP, 8 de enero (1/5), 10 de febrero (1/1), $1(3 / 1)$ y 17 (1/1) de mayo y 23 de julio (2/2) de 1898; ver también "La Doctrina de Monroe", ENP, 16 de octubre de $1898,1 / 2$.

66 Por ejemplo, "La prensa suiza. Europa no debe aceptar la doctrina de Monroe", EG, 18 de abril de 1898, 1/2, referido a un artículo del Diario de Ginebra; "Hungría. España y las grandes potencias", ECE, 30 de mayo de 1898, 2/1; "La prensa yanki y la alemana", EP, 23 de julio de 1898, $2 / 2$. 
vieja Europa no podría mirar con indiferencia una explosión belicosa del spreadeaglismo". "Las cancillerías europeas", advierte, "empiezan a encontrar en la interpretación que dan los americanos a la doctrina de Monroe, un sabor muy marcado de intransigencia. Inglaterra encontraba ayer el veto brutal del Tío Sam entre ella y Caracas, con motivo de la cuestión de Venezuela". En fin, asegura el autor francés que si los Estados Unidos venciera a España en una guerra, "sería insostenible la situación para las naciones que tienen intereses de carácter económico o territorial en aquellas regiones donde la doctrina de Monroe pudiera ser llevada a la práctica". ${ }^{67}$ Incluso cuando los acontecimientos de la guerra de 1898 hacen temer que puedan ser atacados territorios españoles en el Viejo Mundo, se propugna un contra-ataque europeo a la Doctrina Monroe —una especie de 'Europa para los europeos' - "que consista en impedir en absoluto a los Estados Unidos la menor ingerencia en los asuntos europeos". 68

En relación con este aspecto, es interesante comprobar la actitud de la prensa española respecto de Gran Bretaña. Albergando esperanzas de una ayuda británica (y por tanto, previsiblemente, europea) para defender la soberanía española en Cuba, al comienzo de la crisis de 1895-96 se muestra cierta simpatía hacia Gran Bretaña, haciendo votos por una solución pacífica, elogiando la 'sangre fría' de los ingleses, y criticando la postura de Cleveland. ${ }^{69}$

67 “En Cuba”, EG, 3 de marzo de 1898, 1/2. E.R. May: Imperial Democracy...., págs. 181-219, aún ofrece la mejor síntesis de conjunto de las reacciones europeas a la política estadounidense en la coyuntura finisecular, pero se pueden ver también Shippee, Lester B.: "Germany and the SpanishAmerican War". American Historical Review, July, 1925, T. XXX, n. ${ }^{4}$, págs. 754-777; Sears, Louis M.: "French Opinion of the Spanish American War". Hispanic American Historical Review, 1927, t. VII, págs. 25-44; Rippy, J. Fred: “The European Powers and the Spanish-American War", James Sprunt Historical Studies, Chapel Hill, 1927, t. 19, n. ${ }^{2}$, págs. 22-52, principalmente sobre actitudes alemanas; Perkins, A History of...., págs. 196-201, 208-209; Polisensky, Josef: "La guerra hispanocubanoamericana de 1898 y la opinión pública checa", Historica, Praha, 1963, n. o 7, págs. 99-113; MacDonald, J. Frederic: "Jules Cambon et le ménace del 'imperialisme américaine (1898-1899)",

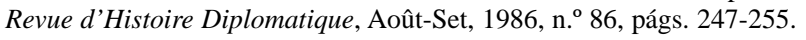
Le Figaro.

68 "La intervención de Europa", EG, 25 de julio de 1898, 1/3, traduciendo un artículo de

69 "Ultimos telegramas", "La cuestión anglo-americana", "La cuestión anglo-americana", y "Carta de Londres", $L E, 2$ de noviembre (3/3), 21 (2/1) y 24 (2/2) de diciembre de 1895, y 6 de enero de 1896, 1/4-5; "Conflicto anglo-venezolano", EP, 3 de noviembre de 1895, 1/3-4; "Ingleses y yankees", "El conflicto anglo-americano. Informaciones", y "El conflicto anglo-americano, LV, 19 (6/1), 21 (sic: 22) (5/2-4) y 25 (1/4-2/1) de diciembre de 1895; "El conflicto de Venezuela", $L J, 14$ de diciembre de 1896, 2/4, dice: "dieron prueba los ingleses del buen sentido que les caracteriza, prescindiendo de cuestiones de amor propio". 
Sin embargo, la aceptación británica de esa intervención, y después su inhibición frente a la política de McKinley, darán lugar a denuncias que de nuevo ponen claramente de manifiesto la relación percibida entre la intervención de 1895 y la de 1898. Para gran parte de la prensa española (como ocurre con la europea, y especialmente la francesa y la alemana), la solución dada a la crisis anglo-americana de 1895 significa no sólo una claudicación egoísta de Gran Bretaña ante las tendencias intervencionistas y hegemónicas de los Estados Unidos, sino que incluso hace temer una posible alianza 'anglosajona', uno de cuyos pilares será el fortalecimiento de la 'nueva' Doctrina Monroe, a resultas de su implícito reconocimiento por la poderosa Gran Bretaña, todo en perjuicio de los intereses europeos y españoles. ${ }^{70}$ Sobre esto comenta El Correo Español: "Desde que los Estados Unidos empezaron a demostrar que su poder naval era de alguna importancia, y que ambicionaban extender sus dominios al amparo o contra la doctrina Monroe, vio Inglaterra que allí encontraría lo que buscaba y tanto le convenía". ${ }^{71}$

En Iberoamérica, las ambivalencias presiden las actitudes acerca de la Doctrina Monroe. Existe una tradición de ensalzarla por cuanto se opone al colonialismo europeo y defiende la auto-determinación de los pueblos americanos, pero al mismo tiempo provoca inquietud el papel dominante que se auto-atribuye el gobierno estadounidense. No obstante, a lo largo del siglo XIX varios países iberoamericanos (incluida Venezuela para su litigio fronterizo con Inglaterra) han reclamado la ayuda de los Estados Unidos en

70 "El arbitraje anglo-americano", y "El Mensaje de Cleveland y la Bolsa”, $L J, 14$ de noviembre (3/3), y 8 de diciembre (3/3) de 1896. En el primero de ellos dice: "Tampoco Inglaterra queda en muy buen lugar cuando se ve obligada a aceptar y reconocer implícitamente la doctrina de Monroe"; "Europa y los Estados Unidos", "La cuestión de Venezuela. Inglaterra y los Estados Unidos", e "Inglaterra y los Estados Unidosy", en $L E, 16$ (3/1 y 3/4;) y 17 (3/1) de noviembre de 1896; "El conflicto anglo-americano" y "La política de arbitraje", en $L V, 15$ (4/3-4) y 18 (6/2) de noviembre de 1896; "La diplomacia de los Estados Unidos", EL, 6 de diciembre de 1896, 2/1-2, dice: "afirmándose constantemente, plegándose a las circunstancias pero sin modificarse nunca, la doctrina Monroe, se ha venido desarrollando hasta obtener su reconocimiento por Inglaterra, en la reciente negociación sobre Venezuela"; "Inglaterra y los Estados Unidos", EP, 2 de junio de 1898, 3/1, informando de una noticia dada en el Daily Telegraph sobre posibles tratados de alianza y arbitraje entre las dos potencias, dice: "La Gran Bretaña reconociendo la doctrina de Monroe aceptaría la interpretación dada a dicha doctrina por los yankis y no intentaría nada para aumentar sus posesiones en América". y "Todos los asuntos que no se relacionen con la doctrina de Monroe o el Canal de Nicaragua serán sometidos a un tribunal interesado"; "Notas parisienses. La opinión ante el conflicto", sobre un artículo de Le Matin y "Un artículo de Castelar", en $E G, 1$ de mayo (2/2) y 28 de octubre (1/4) de 1898. En este último sostiene que el acercamiento anglo-americano desde 1895 quitó a España el importante apoyo británico en 1898.

71 "Inglaterra y los Estados Unidos", ECE, 11 de agosto de 1898, 2/1-2. 
diversos conflictos con potencias europeas, en virtud de la Doctrina Monroe. Por consiguiente, las reacciones iberoamericanas a la intervención de 1895 no son homogéneas. Hay manifestaciones favorables no sólo en Venezuela sino en Colombia, Brasil, Ecuador, Guatemala, El Salvador, y Perú, mientras que dominan el recelo y la hostilidad en Argentina, Chile y México. ${ }^{72}$

En México, por ejemplo, el presidente Porfirio Díaz envía un mensaje al Congreso mexicano el $1 .^{\circ}$ de abril de 1896, propugnando el interés de adherirse a una doctrina que condena las agresiones europeas contra las soberanías americanas; pero añade el "principio Díaz", según el cual cada país americano debería emitir su propia declaración de que cualquier ataque extranjero contra el territorio o la independencia de una república americana tendría que enfrentarse con la solidaridad americana general, en el supuesto de que los Estados Unidos no podría defender toda América en solitario contra las agresiones europeas. Díaz aboga, pues, por la internacionalización de la Doctrina Monroe mediante su definición y su defensa por todo el hemisferio americano. ${ }^{73}$

Las reflexiones que hace para Las Dominicales del Libre Pensamiento desde Buenos Aires un abogado argentino, Luis Varela, ilustran las actitudes hispanoamericanas ante la Doctrina Monroe y los Estados Unidos en el año 1898. "Monroe, con verdadera grandeza de alma, sin ambiciones de dominio ni veleidades de dictador internacional, había señalado a los Estados Unidos una noble misión", y las repúblicas hispanoamericanas han

72 Robertson, William S.: "Hispanic American Appreciations of the Monroe Doctrine", Hispanic American Historical Review, 1920, t. III, págs. 1-16; Rippy, J. Fred: "Some Contemporary Mexican Reactions to President Cleveland's Venezuelan Message", Political Science Quarterly, June, 1924, T. XXXIX, págs. 280-292; Perkins: A History of...., págs. 188-190.

73 Shelby, Charmion C.: "Mexico and the Spanish-American War: Some Contemporary Expressions of Opinion", Essays in Mexican History, Edited by Thomas E. Cotner and Carlos E. Castañeda. Austin, 1958, págs. 226-227 (209-228). Otros estudios sobre reacciones mexicanas a la guerra de 1895-1898 son Gilmore, N. Ray: "Mexico and the Spanish-American War", Hispanic American Historical Review, November, 1963, t. XLIII, n. ${ }^{\text {4 }}$, págs. 511-525; Rodríguez de Magis, M. Elena: "La revolución filipina en la prensa mexicana, 1898-1899”, Historia Mexicana, Octubre-diciembre, 1964, t. 14, n. ${ }^{\circ}$ 2, págs. 311-320; Espinosa Blas, Margarita: "La insurrección cubana de 1895 vista por la prensa michoacana", Tzintzun, Morelia, enero-junio de 1994, n. ${ }^{\circ} 19$, págs. 129-135. Guerra Vilaboy, Sergio: "La revolución independentista de Cuba y la Guerra de 1898 desde la perspectiva de América Latina", Contrastes. Revista de Historia Moderna, Murcia, 1991-1993, núms. 7-8, págs. 65-79, explica la falta de apoyo oficial iberoamericano a la causa independentista cubana en 1898 (que contrasta con la gran solidaridad popular) por el agotamiento del reformismo liberal, la consolidación de oligarquías conservadoras, racistas e hispanófilas, y el rechazo del hegemonismo estadounidense, simbolizado por el "nuevo" monroísmo. 
tenido motivos de agradecer el apoyo estadounidense frente a las injerencias europeas, aplaudiéndose recientemente con "candoroso entusiasmo" la intervención en el litigio anglo-venezolano. Sin embargo, ahora con McKinley se aprecia "una modificación sustancial" en la interpretación de la Doctrina Monroe, arrogándose "el derecho de intervenir, por la fuerza, en las contiendas de los territorios limítrofes". En definitiva, al declarar la guerra a España, McKinley ha traicionado el genuino sentido del monroísmo, y "su mensaje tiene que alarmar a todos los gobiernos de la América Latina, y enajenarle la voluntad y las simpatías de los pueblos que hasta ayer le admiraron". ${ }^{74}$

El abogado argentino no quiere renunciar a lo que percibe de positivo en el mensaje original: "la doctrina de Monroe es amplia, generosa y verdaderamente común en sus consecuencias al interés de todos los pueblos americanos", por lo que opta por acusar a McKinley de traicionar ese espíritu: "las teorías de MacKinley son egoístas, estrechas, mercantiles y sólo peculiares a los Estados Unidos. Monroe hace de su evangelio una fuente de principios de derecho internacional que establecen y confortan la confraternidad y la solidaridad de todas las naciones que ocupan este hemisferio. MacKinley se segrega del concierto de los pueblos de ambas Américas, y preocupado sólo de los intereses materiales de los Estados Unidos, proclama el derecho de la intervención armada sin otro criterio que la propia opinión del gobierno norteamericano, y no para amparar y defender a un pueblo oprimido, sino para atacarlo y acaso destruirlo". ${ }^{75}$

Ahora bien, Varela, advirtiendo que "la doctrina de Monroe ha sido una frase acomodaticia, que ha hecho camino en el mundo jurídico e internacional con un sentido convencional", reconoce que las interpretaciones desvirtuadas no han surgido exclusivamente del afán de promover los intereses estadounidenses. En una clara alusión a la táctica de apropiación y manipulación de declaraciones ajenas para servir los propios intereses, puntualiza que los propios hispanoamericanos han prestado apoyo a la noción errónea de que "las palabras de Monroe envolvían la promesa de una especie de protección política o de tutela de las dos Américas". En fin, opina este abogado, si los Estados Unidos reconociesen la independencia cubana antes de intervenir, "en ese caso su intervención podría aca-

74 Varela, Luis V.: "El fondo de la cuestión", $L D L P, 19$ de mayo de 1898, 1/4 a 2/3.

75 Varela, Luis V.: "España y Estados Unidos. Monroe y MacKinley. Las dos doctrinas". Ibídem, 2 de junio de 1898, 3/3-5. 
so buscar apoyarse en alguna de las interpretaciones dadas a la doctrina de Monroe". ${ }^{76}$

En España, la prensa se muestra consciente de esta ambivalencia iberoamericana, reconociendo por un lado el valor retórico del monroísmo para la defensa de las soberanías americanas frente a las interferencias europeas, pero por otro lado enfatizando el peligro del hegemonismo estadounidense en las Américas. La Epoca lo expresa así: "la doctrina de Monroe, como el dios Jano, tiene dos caras, de las que, si la una expresa simpatía y afecto, la otra expresa soberbia y dominación". ${ }^{77}$

Para El Liberal, las repúblicas iberoamericanas cometen un error al abrazar la Doctrina Monroe, "tomada sin razón por base del panamericanismo" ${ }^{78}$ y poco después, estando a punto de estallar la crisis anglo-americana, informa que la prensa neoyorquina publicó una carta del insurrecto cubano Carlos Roloff, quien, "para hacerse más simpático a los americanos, concluye con estas palabras 'La doctrina de Monroe debe ponerse en vigor: América para los americanos" ${ }^{\prime} .{ }^{79}$

En toda la prensa peninsular de estos años, es bastante frecuente ver lúgubres advertencias acerca de las pretensiones tutelares y hegemónicas de los Estados Unidos en las Américas. ${ }^{80}$

76 Varela, Luis V.: "España y Estados Unidos. Monroe y MacKinley", $L D L P, 26$ de mayo de 1898, 3/3 a 4/1. Richard Olney en carta de 24 de diciembre de 1896 (cit. en Eggert, Gerald G.: Richard Olney: Evolution of a Statesman. University Park, 1974, pág. 266) pensó que su gobierno no podía reconocer la independencia de Cuba después de la interpretación dada a la Doctrina Monroe en 1895, porque eso le habría obligado inmediatamente a declarar la guerra a España. Si McKinley compartía ese análisis, contribuiría a explicar porqué se opuso siempre a tal reconocimiento (al margen de interpretaciones que ven sólo maquiavelismos colonialistas en su política), y porqué nunca utilizó la Doctrina para justificar su propia intervención en el conflicto hispano-cubano. Sin embargo los comentaristas españoles, empeñados en tachar la política de McKinley de monroísta, no analizan este argumento.

77 "La cuestión de Venezuela", LE, 24 de octubre de 1895, 1/1. "España en América”, EP, 25 de octubre de 1895, 1/2, utiliza la misma imagen: "la Doctrina de Monroe, como el dios Jano, tiene para las naciones de América latina dos caras..".

78 "La beligerancia de los insurrectos cubanos", EL, 18 de octubre de 1895, 1/2.

79 "Carta de Nueva York", EL, 12 de diciembre de 1895, 1/3.

80 Véase por ejemplo, Castelar, Emilio: "La insurrección cubana y los periódicos extranjeros", $D C, 8$ de septiembre de 1895, repr. en Baraja, La guerra de..., págs. 233-235; "La cuestión de Venezuela", "La cuestión anglo-americana", "Inglaterra y los Estados Unidos" y "Carta de Londres", en $L E, 24$ de octubre (1/1) y $21(2 / 1)$ y 22 (1/1) de diciembre de 1895, y 6 de enero (1/4-5) de 1896; "España en América" y "Venezuela y los Estados Unidos" en EP, 25 de octubre (1/2) y 22 de diciembre (1/2) de 1895; "El mensaje presidencial" y "El americanismo contra Europa", en $L V, 20$ de diciembre de 1895, 5/3 y 23 de enero de 1896, 1/2-3; "Cleveland", "Extranjero-Venezuela" y "América y Europa", en ENR, 21 (1/4-2/1) y 28 (3/1-2) de diciembre de 1895 y 4 de enero (1/3) de 1896. También Labra: Aspecto internacional...., págs. 229-230. 
Así, por ejemplo, a raíz de la crisis de 1895 comenta El Nuevo Régimen: "Sin duda que es inaplicable la egoista doctrina de Monroe;.. Es censurable que los Estados Unidos quieran ejercer una tutela sobre todos los demás pueblos americanos...", ${ }^{81}$ y poco después: "Fuerza Cleveland la significación y el sentido de la doctrina de Monroe,... se inmiscuye en el régimen político de las Repúblicas, ayer colonias;... con el claro y manifiesto fin de conseguir para su pueblo la hegemonía de las naciones americanas...". ${ }^{82}$ Por su parte, La Justicia juzga: "La situación de Venezuela resulta, por lo tanto, humillante con esta solución, pues siendo la principal interesada, queda bajo una especie de tutela de los Estados Unidos". ${ }^{83}$

Mientras tanto, El País revela sus propias incoherencias imperialistas, soñando con una república española que presida una hegemonía latina que se oponga al hegemonismo monroísta: "España republicana... sería el lazo de unión entre todas las naciones ibéricas del uno y el otro continente, y la Doctrina de Monroe, absorbente, egoista, utilitaria, tras la cual se esconde la ambición yankee, sería sustituída por el principio más lógico y más positivo de la hegemonía de la raza latina en América, que bien pudiera aplicarse a la hegemonía de la raza latina en todo el globo". ${ }^{84}$

Ya en el contexto del conflicto hispano-cubano, advierte el Diario de Cádiz: "la anexión de Cuba a los Estados Unidos sería la señal de alarma para todas las naciones americanas, que comprenderían entonces por los hechos la verdadera significación de la doctrina de Monroe...". ${ }^{85}$ Asimismo, El Nuevo País reproduce un artículo de Rubén Darío publicado en El Tiempo de Buenos Aires, que, solidarizándose con España, denuncia vehementemente la Doctrina Monroe, al mismo tiempo que lamenta la falta de coherencia de algunos países iberoamericanos al respecto. ${ }^{86}$

81 "Extranjero. Venezuela", ENR, 28 de diciembre de 1895, 3/1-2.

82 "América y Europa", Ibídem, 4 de enero de 1896, 1/3.

83 "El arbitraje anglo-americano", y "El conflicto de Venezuela", en $L J, 14$ de noviembre (3/3) y 14 de diciembre (2/4) de 1896; este último, comentando el inicial entusiasmo venezolano por la intervención de Cleveland, dice: "los venezolanos se llaman ahora a engaño".

84 "España en América", EP, 25 de octubre de 1895, 1/2. Serrano, Final del Imperio....., págs. 79-80, comenta sueños similares acariciados por Salmerón.

85 El corresponsal en Madrid del DC, 4 de septiembre de 1897, repr. en Baraja: La guerra de..., págs. 290-291.

86 Darío, Rubén: "El triunfo de Calibán. Contra los yankis”, ENP, 21 de agosto de 1898, 3/1-3: "sus grandes hombres, como no sea Edison, se llaman Lynch, Monroe, y ese Grant"; "Roque Sáenz Peña, el argentino cuya voz en el Congreso panamericano opuso al slang fanfarrón de Monroe una alta fórmula de grandeza continental, y demostró en su propia casa al piel roja que hay quienes velan en nuestras Repúblicas por la asechanza de la boca del bárbaro". 
Por su parte, El Correo Español, muy escéptico sobre la esperanza de la posible ayuda europea, cree que "el aliado natural de España contra los Estados Unidos, cuyas tendencias absorbentes no son nuevas,... no está en Europa, sino en la misma América... los pueblos que pertenecen a nuestra raza,... Esos pueblos, en fin, han sido los primeros en compenetrarse de que la doctrina de Monroe es una añagaza vilísima para esclavizarlos, puesto que los yankees no aspiran a que América sea para los americanos, como esa doctrina enseña, sino a que sea para los Estados Unidos...." ${ }^{87}$

Sin embargo, pese a estas advertencias, no se aprecia en la mayor parte de la prensa española una verdadera corriente de opinión solidaria con los intereses iberoamericanos. Enjuiciando el contexto internacional de la guerra cubana, Rafael María de Labra se lamenta de que el gobierno español no haya tratado ni trate de movilizar las simpatías hispanoamericanas a favor de España, al tiempo que deplora la falta de una clara propuesta de política iberoamericanista global por parte de la diplomacia española ${ }^{88}$ En efecto, la mayoría de las denuncias periodísticas españolas de las intervenciones de Cleveland y McKinley representan una perspectiva colonialista a ultranza. Resultan significativos los intentos españoles de fomentar la solidaridad colonial europea frente a la Doctrina Monroe, desde la perspectiva de los movimientos panamericano, iberoamericanista, hispanoamericanista, y anticolonialista finiseculares, pues evidentemente, si las repúblicas hispanoamericanas miran al monroísmo con ambivalencia, la postura colonialista de la monarquía española no les puede resultar menos desalentadora.

\section{Conclusiones}

La mayoría de los periódicos peninsulares relacionan insistentemente la intervención de Cleveland en el litigio anglo-venezolano con la de McKinley en el conflicto hispano-cubano, apreciándose una clara conciencia de que se inaugura una nueva etapa en la política exterior de los Estados Unidos. Más concretamente, estas comparaciones se centran en diversas valoraciones de la Doctrina Monroe y de su significación como fundamento teórico y justificación de la acción exterior estadounidense. La tradicio-

87 "Aún es tiempo", ECE, 19 de marzo de 1898, 1/2.

88 Labra: Aspecto internacional...., págs. 73-97. 
nal interpretación conservadora de esta Doctrina como garantía para las posesiones españolas en el Caribe pierde fuerza a raíz de la crisis angloamericana de 1895, perfilándose el 'nuevo' monroísmo como una amenaza creciente.

Ahora bien, no se aprecia una homogeneidad de criterios en la argumentación española surgida en torno a la Doctrina Monroe en estos años. Tan pronto aparecen intentos de utilizarla, desde una construcción 'primitiva' favorable y restrictiva, para contener o desautorizar el intervencionismo estadounidense, como se la condena por considerar que simboliza todo cuanto hace recelar de la política del coloso americano: su poderío económico, su expansionismo comercial y naval, su afán de hegemonismo en las Américas, su arrogancia en el concierto de las naciones.

Lo que sí tienen en común la gran mayoría es su punto de partida: la suposición de que la política de McKinley ante la crisis colonial española es, de hecho, una función de la Doctrina Monroe. Apenas se encuentran ecos en la prensa peninsular de los argumentos anti-imperialistas de inspiración monroísta que se esgrimen en los debates del Congreso estadounidense, y en cambio al gobierno de McKinley se le atribuye y se le critica repetidamente su monroísmo. Como es inexacto que McKinley utilice la Doctrina como justificación o explicación de su política en 1898, es necesario e interesante preguntarse porqué se plantea el discurso periodístico español en estos términos.

Parece razonable interpretar este aparente divorcio entre la realidad discursiva del gobierno de McKinley y la respuesta española, no en función del (insignificante) peso real de la Doctrina Monroe en las justificaciones oficiales estadounidenses de 1898, sino en función de otras consideraciones relacionadas con la política doméstica peninsular y con los recursos y objetivos propagandísticos de la prensa periódica.

Las posturas mayoritarias muestran una fuerte carga de anti-yanquismo. En su caso, cabe argumentar que es irrelevante el hecho de que McKinley no mencione la Doctrina de forma explícita, toda vez que el monroísmo ('nuevo', o ‘viejo' y esencialmente inalterable, según los argumentos) se reconoce como poderosa influencia real subyacente en toda su política. En el supuesto de que la Doctrina Monroe es percibida y despreciada por muchos comentaristas europeos e iberoamericanos como una pretensión unilateral, egoísta, arbitraria, y de tendencias expansionistas cuando no hegemónicas, centrar la atención crítica en ella se convierte en un recurso retórico valioso en el intento de movilizar la opinión pública 
española e internacional contra los Estados Unidos, inflamando las pasiones anti-estadounidenses populares y patrioteras.

Ahora bien, encierra una contradicción patente este intento de apelar a la solidaridad con España de las monarquías europeas que conservan intereses coloniales en América, y al mismo tiempo, promover los recelos nacionales iberoamericanos contra los Estados Unidos, puesto que se trata de dos discursos que son fundamentalmente incompatibles. Esto pone de manifiesto que el elemento dominante de este discurso es el sentimiento anti-yanqui y no la propia coherencia de sus argumentos en su conjunto.

Los defensores de la interpretación más idealista del mensaje de Monroe representan una pequeña minoría, desbordada por la ola despreciativa de McKinley, del monroísmo, y de todo lo norteamericano, que predomina en la prensa española. Asumen la futilidad de intentar disociar la Doctrina Monroe de la política de McKinley, y optan por arguir que el supuesto monroísmo de McKinley en realidad no es tal, sino que subvierte el 'verdadero' espíritu de dicha Doctrina, al pretender ponerla al servicio exclusivo de los intereses estadounidenses. Así pues, al igual que la reacción anti-yanqui, esta respuesta obedece a unos objetivos retóricos al margen de los términos del discurso oficial de McKinley en 1898. Se trata no sólo de contener las tendencias hegemónicas de los Estados Unidos, sino de defender y promover unos valores internacionales solidarios y progresistas de alta significación ética. Para ello, aplica la táctica discursiva de apropiarse, mediante el ensalzamiento, de los propios símbolos y héroes nacionales estadounidenses como recurso retórico. En definitiva, se trata de salvar a Monroe como símbolo de solidaridad democrática internacional, para lo cual es preciso distanciar su mensaje 'original' de la 'nueva' interpretación de 1895, y desacreditar la política de McKinley como ruptura y traición respecto de los más genuinos valores y tradiciones nacionales estadounidenses. 